\title{
Organizational identity construction of the world's top universities: A discourse analysis of university prospectuses
}

\author{
MEIMEI YANG
}

Received 13.01.2019, received in revised form 13.03.2019,

accepted 21.03.2019.

\begin{abstract}
A prospectus, as a kind of self-description of the organization, is specified as one of the attributes of an organization. A university, as a type of organization, makes its prospectus accordingly. A prospectus - as a genre of organizational discourse - has a constructive mechanism. With the synergy of the discoursehistorical approach (DHA) and the corpus discourse approach, this article will analyze - using WordSmith - the discursive strategies involved in the construction of the organizational identity of the world's top universities. The analysis reveals that the prospectuses of the world's top 100 universities mainly employ the referential/nomination strategy and predication strategy to construct an identity for themselves as world-renowned, diversified, reputable leading universities which will participate positively in the global market.
\end{abstract}

\section{Keywords}

university prospectus, discursive construction, organizational identity, corpus linguistics, DHA 


\title{
Budowa tożsamości organizacyjnej najlepszych uniwersytetów na świecie: Analiza dyskursu prospektów uniwersyteckich
}

\begin{abstract}
Abstrakt
Prospekt jako rodzaj opisu organizacji jest określony jako jeden $z$ atrybutów organizacji. Prospekt, który jest gatunkiem dyskursu organizacyjnego, posiada swój konstruktywny mechanizm. Dzięki synergii podejścia dyskursywno-historycznego i dyskursu korpusowego, artykuł ten przeanalizuje przy pomocy WordSmith strategie dyskursywne wykorzystywane $\mathrm{w}$ konstruowaniu tożsamości organizacyjnej najlepszych uniwersytetów na świecie. Analiza pokazuje, że prospekty tych 100 najlepszych uniwersytetów na świecie wykorzystuja głównie strategię nominacji i strategię predykatywna, aby budować swój obraz jako uniwersytetu wiodącego, zdywersyfikowanego, renomowanego, który $z$ sukcesem bierze udział $\mathrm{w}$ globalnej konkurencji.
\end{abstract}

\section{Słowa kluczowe}

prospekt uniwersytetu, konstrukcja dyskursywna, tożsamość organizacyjna, językoznawstwo korpusowe, podejście dyskursywnohistoryczne

\section{Introduction}

Identity is increasingly used as "an analytic tool for studying important issues of theories and practices in education" (Gee 2001: 100) as it bears value with the unique status of being an ideal interface to liaise the micro discursive features and macro social practice or events (Lemke 2008). In other words, identity can be a very suitable lens through which to integrate discourse and practice, that is, identity-in-discourse and identity-in practice (Varghese et al. 2005). From a micro perspective, identities are also conceived of as being constructed and reflected in discourse. 
Organizational identity is defined as a set of statements that organization members perceive to be central, distinctive and enduring to their organization (Albert and Whetten 1985). Organizational identity is seen as a way to distinguish one entity from another, to signify an organization's selfdetermined, unique social space and to reflect its unique pattern of binding commitments (Whetten 2006: 220).

The prospectus of an organization is both a first impression to others and a way to demonstrate something about the organization itself. Outside of geographical boundaries, communication and collaboration with both domestic and foreign partners is a necessity for universities; therefore, the prospectus is a means of self-introduction which plays a vital role in the construction of organizational identity.

In the hopes of serving as an expedition, this article aims to explore the organizational identity of higher learning institutions by the discursive analysis of university prospectuses. Prospectuses published online are a way for universities to construct identity. Wodak's (2001) discoursehistorical approach will serve as the theoretical framework and permeate the study to interpret organizational identity at the institutional level. The article aims to answer the following research questions: 1 . What kind of organizational identity would the university like to construct through its prospectus and 2. What kind of discursive devices have been used to construct this identity.

\section{Theoretical framework}

\subsection{Corpus linguistics}

Corpus linguistics (CL), the term first used by Aarts and Meijs (1984), is broadly utilized in linguistic research areas. Owing to the nature of CL "cutting edge change in terms of scientific techniques and methods" (McCarthy 2001), the compiling and design of the corpus needs its specific tools and methods. In response to the critics of $\mathrm{CL}$, compiling specialized small 
corpuses for a specific use has become a new trend of corpus analysis due to its advantages for discourse analysis.

Scholars of different research focuses (analyzers of business discourse, media discourse, institutional discourse, professional discourse etc.) try to compile their own specialized corpora for their specific studies. Hyland (2002, 2004) and Flowerdew (2008) built their own specialized corpus for pedagogical purposes. Koester (2010) designed a specialized corpus-ABOT (American and British Office Talk) with 34,000 words from different institutions in Britain and North America. Kristy Beers Fagersten (2010) compiled her own small corpus with 100,000 words from different genres for hip-hop identity analysis, Anna Marchi and Charlotte Taylor (2010) built a 1,340,156 word corpus from different newspapers for identity analysis etc.

The construction of a specialized small corpus is a new trend for discourse analysis due to its merits. In accordance with the above analysis, this article will design a specialized corpus for the purpose of digging out the linguistic devices beyond lines.

\subsection{DHA as a branch of CDA}

Viennese Critical Discourse Analysis (CDA) adopted the historical discourse approach, attempting to render a kind of connection between specific linguistic subsystems and social structure. Wodak's historical discourse approach includes triangulation, meaning that discursive phenomena are approached from a variety of methodological and theoretical perspectives taken from various disciplines (Wodak 2009), and linguistic analysis consisting of strategy analysis and topoi of these two parts.

"Strategy" is a kind of specific intentional scheme oriented to reach distinguished social, political, psychological and linguistic purposes (Wodak and Meyer 2001). According to the Viennese School of discourse analysis, "behavior" is the realization of "strategy" and "strategy" is a way to reach 
specific goals. "Discourse strategy" serves as the application of a language system, reflecting different levels of language structures and implying different aims and goals. There are four typical "discourse strategies" adopted by the Viennese School from macro-perspectives: constructive strategies, justificatory strategies, transformative strategies, and destructive strategies. The above macro-strategies have different ways of being realized due to different materials which are analyzed. These four macro discourse strategies can also be divided into six frequently practiced micro-strategies: nomination, predication, argumentation, perspectivization, mitigation and intensification. This article will take nomination and predication as two strategies to identify the linguistic devices in the construction of organizational identities.

\subsection{Corpus linguistics and DHA}

Though combining CDA and CL is not a new endeavor, the combinations performed by previous researchers and scholars have always been unbalanced with either CDA or CL as subservient. One of the most popular combinations is Corpus-Assisted Discourse (CAD). The CAD approach serves as a discourse analyzing method combining the quantitative rigor of corpus linguistics with the qualitative social perspective of more traditional discourse analysis (Marchi and Taylor 2010), which serves CL as technically assisting catering to the discourse analysis. In opposition to the imbalanced combination, Paul Baker and Ruth Wodak (2008) attempt to show that neither CDA nor CL needs to be subservient if there is proper synergy (Wodak and Baker 2008).

The Viennese Critical Discourse Analysis adopts the historical discourse approach, attempting to render a kind of connection between specific linguistic subsystems and social structure. As has been mentioned, Wodak's historical discourse approach includes triangulation, meaning that 
discursive phenomena are approached from a variety of methodological and theoretical perspectives taken from various disciplines (Wodak 2009) and linguistic analysis consisting of strategy analysis and the topoi of these two parts.

A mixed method will be used to analyze the discursive identity construction of the world's top universities. By applying Wodak's (2001) discourse-historical theory and using WordSmith as a technical tool, the article will initially choose linguistic devices such as modality, evaluation, metaphor etc. WordSmith Tool 6.0 (2012) will be employed to search for their distribution in the corpus comprised of the collected texts.

\section{Data analysis}

\subsection{Data sources}

A purpose-oriented specific corpus was designed in accordance with the research aims and focus. The dataset for this article consists of 100 university prospectuses. The universities have been taken from the list of top universities, 2018-2019 QS ranking, available at <https://www.topuni versities.com>. All of the descriptions have been retrieved from the official websites of the top 100 universities. The corpus consists of approximately 60,000 words.

\subsection{Data content}

Most prospectuses contain information about the individual university's mission and value statements, figures, honors and prizes, ranking, history, education/teaching, research, organization, global standing, and notable alumni. From all of these categories, education/teaching, and research are the priorities in prospectuses. 


\section{Data research and methodology}

By "strategy", we generally mean more or less a plan of practices including discursive practices adopted to achieve particular social, political, psychological or linguistic goals. Discursive strategies are located at different levels of linguistic organization and complexity (Reisigl and Wodak 2009: 94). Different discursive strategies applied by universities in their prospectuses will be identified. As has been mentioned, this article explores two discursive strategies: nomination and prediction.

\subsection{Nomination/referential strategy}

The objective of a nomination/referential strategy is the construction of "in-groups" and "out groups". "Insiders" and "outsiders" are two typical membership identities constructed by referential strategies through different devices such as membership categorization, metaphor and metonymy (Wodak 2001).

\subsubsection{Personal pronouns: we and our}

Personal pronouns are some of the most frequently used devices in the referential strategy. They accurately represent the actors' attitudes and orientations - as will be demonstrated in this section. We, they, $I$ and their variants are all used for personal reference with different connotations and meanings. This section will mainly focus on the use of $w e$ and our.

The first person pronouns are widely studied and acknowledged as functional words with different connotations. Generally, linguists claim that the pronoun we has two senses: inclusive and exclusive. Inclusive we means that there exists something which may connect the sender and receiver, narrowing the psychological distance and strengthening the cohesion between them. Exclusive we is used to 
separate the sender and the receiver. Furthermore, in accordance with Wodak (2009), the above categorization remains fairly broad. The use of we will be explored in the organizational identity construction.

By making a word list with Wordsmith, it is possible to see that both we and us are high-frequency words, as in the examples below:

(1) This is the fundamental purpose of the national university, which we will remain as long as we continue to serve Australia with distinction. (The Australian National University)

(2) We expect our actions to be consistent with our words, and our words to be consistent with our intentions. (Purdue University)

(3) We actively promote equal opportunities for women and men. We are also determined to become Germany's most attractive technical university for women. (Technical University of Munich)

(4) We champion and support our students so they have a memorable university experience. (Monash University)

(5) We pioneer innovative research that tackles global problems and expands the human experience. (University of Illinois at Urbana-Champaign)

It appears that the top 100 universities use we to distinguish themselves from others so as to demonstrate their advantages as world-class universities. From the above examples it follows that these universities all use we and our, creating an "insider" point of reference.

\subsubsection{The we $+\mathrm{V}$ structure}

By using the collocate function of Wordsmith, the we $+\mathrm{V}$ structure will be investigated. We assume that the predicate $\mathrm{V}$ may act as the reflection of the sender's emotions.

After searching the pronoun we in the we $+\mathrm{V}$ structure, with the L5 and R5 setting of the search word, the results 
demonstrate that we will and we must are high-frequency strings of words. Fowler (1996) points out that a modal verb, as the expression of human emotions and attitudes greatly reflects the sender's stance on different topics.

Searching the corpus, we find that the pronoun we is found to occur with verbs belonging to two categories: the modal verbs (MV) and the notional verbs (NV). The modal verbs must and will belong to the high and medium value modal verbs, so we can claim that they reflect the universities' determination to take action.

Table 1

\begin{tabular}{|l|l|}
\hline Modal Verbs & Notional Verbs \\
\hline (We) will & $\begin{array}{l}\text { explore, continue, strengthen, impact, } \\
\text { better, expand, grow, increase, enhance, } \\
\text { (actively) pursue, lead, develop, promote, } \\
\text { foster, build, remain, seek, revitalize, } \\
\text { nurture }\end{array}$ \\
\hline (We) must & $\begin{array}{l}\text { re-envision, equip, ensure, endeavor, } \\
\text { diversify, invest in, insist on, equip, inspire }\end{array}$ \\
\hline
\end{tabular}

Table 1 demonstrates that we will and we must largely cooccur with notional verbs which have positive connotations. The following examples illustrate the use of the structure we $+\mathrm{MV}+\mathrm{NV}$ in the university prospectuses.

(6) We will continue to explore new scientific fields while further developing our existing disciplines. (Eindhoven University of Technology)

(7) We will enhance their experiences by embedding their education in cutting-edge research. (Imperial College London) 
(8) We will strengthen our reputation, increasing our national and international rankings to secure a position in the top 10 in the UK and top 100 internationally. (The University of Southampton)

(9) We will have impact locally, nationally and globally through transformational learning experiences and groundbreaking scholarship. (University of Illinois at Urbana-Champaign)

(10) In order for our students and staff to positively impact their communities and the world, we must equip them and inspire them so they can be agents of change in our history. (Monash University).

Analyzing the pronoun we and the $w e+M V+N V$ structure, it is possible to see that these universities attempt to present themselves as highly respected universities which are different from their competitors.

\subsection{Predication}

Strategies of predication are ways to assign positive and negative attributes to certain people or communities through evaluation systems to demonstrate different attitudes, the baseline objective of which is to label social actors positively or negatively (Reisigl and Wodak 2017). We will explore the ways of constructing organizational identity by analyzing predicates, semiotic prosody and comparison.

\subsubsection{Predicate analysis}

Predicates (including predicative adjectives and pronouns) are all the discursive realizations of the strategy of nomination. This article will explore the employment of predicates in the university prospectuses.

Taking three high-frequency words - research, education and teaching - as search words, exploring the predicates with the L5 and R5 setting, it is possible to see that the predicates which collocate with the above words are the following: strengthen, enhance, focus, impact, boost, leading, trans- 
formative, beneficial, inspiring, influential, transform, inspired, grow, e.g.

(11) [...] to boost its research capabilities, a strategy which has helped establish its reputation today as an international centre of research excellence. (University of St Andrews)

(12) These universities are regarded as the nation's leading research and comprehensive institutions. (Adelaide University)

(13) To conduct interdisciplinary and innovative research that addresses pressing challenges facing the world today. (Zhejiang University)

(14) It strives not only for improvements in teaching and research work, but also for the promotion of interaction and mutual promotion among various disciplines. (Peking University)

(15) We are entering a momentous chapter in our history, one that will transform our teaching, learning and research spaces. (University of Glasgow)

In these examples, the employed word combinations (boost [...] research capabilities, innovative research, improvements in teaching and research work, transform our teaching, learning and research spaces) imply that changes are necessary to improve research and/or teaching at these universities.

\subsubsection{Analyzing semiotic prosody}

\subsubsection{Positive semiotic words}

Semantically speaking, lexical meaning can be divided into different categories in accordance with different semiotic prosody. Taking research, education and teaching as search words and exploring their collocations with the L5 and R5 setting, we obtain the following adjectives co-occurring with these three words: meaningful, excellent, key, world-class, top, powerful, strong, premier, great, high-level, new, cutting-edge, prestigious, top-level, fundamental, distinguished, exceptional, 
core, significant, world-renowned, competitive, prestigious etc. All of them are words of positive semiotic prosody. As the selected examples demonstrate, these words are used mainly to describe the universities as research and teaching institutions.

(16) Penn is one of the world's most powerful research and teaching institutions. (Pennsylvania State University)

(17) UM is one of Malaysia's premier Research Universities and one of the leading Research Universities in Asia. (University of Malaya)

(18) [...] replete with cutting-edge research equipment [...] (Korea University)

(19) [...] become a crown jewel as a top research university specialized in science, technology, engineering and math (STEM). (Pohang University of Science and Technology)

(20) [...] the University of Zurich belongs to Europe's most prestigious research institutions. (University of Zurich)

\subsubsection{Compound words}

Searching the corpus, we have found some compound words: research-intensive, research-led, research-driven, researchinformed, research-based, research-oriented, research-focused. The lexemes intensive, led, driven, informed, based, oriented, focused which follow research highlight the importance of research conducted at the universities.

\subsubsection{Comparison}

Exploring the content of the prospectuses, we find that some of the universities use words which serve them to compare themselves with other universities, their students, their locations etc.: most, highest, strongest, best, first, primary etc. Examples of comparisons are the following: 
(21) [...] it is now a large, comprehensive public university, grounded in its civic roots in New Zealand's most diverse city. (The University of Auckland)

(22) The talents of some of the UK's most influential political figures have been nurtured here. (University of Glasgow)

(23) 1'X naturally seeks to share the most up-to-date knowledge to benefit its students. (Ecole Polytechnique)

(24) CityU has established itself as one of the most innovative universities in Asia. (City University of Hong Kong)

(25) [...] recognized as North America's most international university. (University of British Columbia)

\section{Conclusion}

This article surveys university identity construction by the methodology of synergizing DHA and CL. From the above analysis, it is possible to see that these top 100 universities use nomination/referential strategy to distinguish themselves from others so as to highlight their own distinctive characteristics and unparalleled reputation. Furthermore, they use the predication strategy to depict themselves as world-renowned, diversified, reputable leading universities who will participate positively in the global market.

There is a close linkage between language and organizational identity construction. Organizational identity can be constructed by different strategies and linguistic devices are technical methods for organizational identity construction.

Additionally, as a successful practice of the combination of DHA and CL in organizational identity study, this article explores the linguistic devices employed in university prospectuses, which opens the way for further study in this area. 


\section{References}

Alameda Hernández, Angela (2006). The Discursive Construction of Gibraltarian Identity in the Press: A Critical Discourse Analysis of Editorial Articles on the Gibraltar Issue. PhD dissertation, University of Granada.

Albert, Stuart, David A. Whetten (1985). "Organizational identity". Research in Organizational Behavior 7: 263-295.

Baker, Paul (2006). Using Corpora in Discourse Analysis. London: Continuum International Publishing Group.

Baker, Paul, et al. (2008). "A useful methodological synergy? Combining critical discourse analysis and corpus linguistics to exam discourses of refugees and asylum seekers in the UK press". Discourse and Society 19/3: 273-306.

Bhatia, Vijay Kumar (2004). Worlds of Written Discourse: A GenreBased View. London: AandC Black.

Blommaert, Jan (2005). Discourse: A Critical Introduction. Cambridge: Cambridge University Press, 2005.

Blommaert, Jan, et al. (2000). "Critical Discourse Analysis". Annual Review of Anthropology 29/1: 447-466.

Cheney, George (1983). "On the various and changing meanings of organizational membership: A field study of organizational identification". Communication Monographs 50/4: 342-362.

Gee, James Paul (2001). "Identity as an analytic lens for research in education". Review of Research in Education 25/1: 99-125.

Lemke, Jay L. (2008). "Identity, development and desire: Critical questions". In: Carmen Rosa Caldas-Coulthard, Rick Iedema (eds.). Identity Trouble: Critical Discourse and Contested Identities. New York: Palgrave Macmillan, 17-42.

Martin, Reisigl, Ruth Wodak (2017). "The discourse-historical approach". In: John Flowerdew, John E. Richardson (eds.), The Routledge Handbook of Critical Discourse Studies. London: Routledge, 44-59.

McCarthy, John J. (2001). A Thematic Guide to Optimality Theory. Cambridge: Cambridge University Press.

Reisigl, Martin, Ruth Wodak (2001). Discourse and Discrimination: Rhetorics of Racism and Antisemitism. London: Routledge.

Scott, Mike (2008). Wordsmith Tools Version 4. Liverpool: Lexical Analysis Software.

Seidl, David, et al. (2006). "Organizations as distinction generating 
and processing systems: Niklas Luhmann's contribution to organization studies". Organization 13/1: 9-35.

Sun Yongmei, Zhang Yanbin (2013). "Cóng "běidà jiănjiè" kàn dàxué shēnfèn de huàyǔ jiàngòu”. Zhōngguó shèhuì yǔyán xué 1: 66-74 [孙咏梅, 张艳斌 (2013). 从“北大简介”看大学身份的话语建构 “The discursive construction of organizational identity: The case study of Beijing university's prospectus on the web'. 中国社会语言学 'The Journal of Chinese Sociolinguistics' 1: 66-74].

Whetten, David A., Paul C. Godfrey (1998). Identity in Organizations: Building Identity through Conversations. London: SAGE Publications LTD.

Wodak, Ruth (2001). "The discourse-historical approach". In: Ruth Wodak, Michael Meyer (eds.). Methods of Critical Discourse Analysis. London: Sage Publications, 89-95.

Wodak, Ruth (2011). "Critical linguistics and Critical Discourse Analysis". In: Jan-Ola Östman, Jef Verschueren (eds.). Handbook of Pragmatics. Amsterdam: John Benjamins Publications, 50-70.

Wodak, Ruth, et al. (2009). The Discursive Construction of National Identity. 2nd edition. London: Edinburgh University Press.

Young, Lynne, Claire Harrison (2004). Systemic Functional Linguistics and Critical Discourse Analysis: Studies in Social Change. New York: Continuum Publishing Corporation.

Meimei Yang

ORCID iD: 0000-0002-9120-1611

\#20 International Office

Ningbo University

818 Fenghua Road

Jiangbei District

Ningbo 315211

China

yangmeimei@nbu.edu.cn 